\title{
THE UPPER MANTLE HETEROGENEITY: THERMODINAMIC CALCULATIONS AND METHODS OF MATHEMATICAL STATISTICS
}

\author{
Lucy N. Pokhilenko, Anatoly A. Tomilenko, Sergey S. Kuligin, Vladimir V. Khlestov \\ Institute of Mineralogy and Petrography SB RAS, Russia
}

\section{INTRODUCTION}

The P-T conditions of formation of mantle rock have been a long-standing problem. Investigators used various thermometers and barometers, developed new approaches to evaluate P-T parameters, refined calculational equations to minimize uncertainty, etc. The redox conditions of the upper mantle are of great interest, because mantle fluids take part in the formation of rocks, minerals and ores (Letnikov, 1999). The studies of the fluid regime of formation of mantle rocks (Melton, 1974; Andersen, 1984; Jakobsson, 1990; Daniels, 1991; Schrauder, 1994) have shown that $\mathrm{H}_{2} \mathrm{O}$, $\mathrm{CO}_{2}$ and $\mathrm{CH}_{4}$ are the dominant volatile components of the upper mantle. Depending on the oxygen potential in the given mantle area, either $\mathrm{CO}_{2}$ or $\mathrm{CH}_{4}$ may dominate the fluid composition (Kadik, 1999). In this paper we describe algorithm of discrimination of mantle rocks of different genesis on the basis of the two independent sets of parameters: (1) fugacity of oxygen at conditions of P-T equilibrium of the rocks; and (2) the content of major oxides comprising the mantle minerals.

\section{SAMPLES}

Xenoliths of different genesis from kimberlite pipes of Yakutia (Udachnaya, Mir, Zagadochnaya, Obnazhennaya) and South Africa (Roberts Victor) have been studied. The studied samples can be referred to the following petrographic rock types according to the structure and mineral composition: Harzburgite-Dunite - HD - $\left(\mathrm{Ol}+\mathrm{Ga} \pm \mathrm{Chr}_{ \pm} \mathrm{Op} \underline{\mathrm{O}}+\mathrm{D}\right)-22$ samples, Garnet Lherzolite $-\mathrm{GaL}-(\mathrm{Ol}+\mathrm{Ga}+\mathrm{Opx}+\mathrm{Cpx})-29$ samples, Garnet-Spinel Lherzolite - GaSpL $(\mathrm{Ol}+\mathrm{Ga}+\mathrm{Sp}+\mathrm{Opx}+\mathrm{Cpx})-12$ samples, Spinel Lherzolite - SpL - $(\mathrm{Ol}+\mathrm{Sp}+\mathrm{Opx}+\mathrm{Cpx})$ - 13 samples, Sheared Peridotite - $\mathrm{ShP}-(\mathrm{Ol}+\mathrm{Ga}+\mathrm{Cpx} \pm \mathrm{Opx} \pm \mathrm{Il})-24$ samples, Eclogite - Ecl - $(\mathrm{Ga}+\mathrm{Cpx} \pm \mathrm{Ky} \pm \mathrm{D})-21$ samples and Pyroxenite - Pyx - (Ga+Cpx \pm Opx $)-24$ samples.

\section{METHODS}

\section{MICROPROBE ANALYSIS AND DETERMINATIONOF PT-CONDITIONS OF THE EQUILIBRIUM OF MANTLE ROCKS}

The determination of mineral phase composition of the studied rocks has been conducted with the use of a CAMEBAX-MICRO X-ray microprobe (CAMECA, France). The microprobe analysis of their components has been made and the P-T conditions of the equilibrium of these rocks have been determined using the code Terra55 (by I.V. Ashchepkov; UIGGM, Novosibirsk). This code includes some tens of the most known thermometers and barometers and allows using a few pairs simultaneously for determination of the PT data of the mantle rocks of different genesis. Since most of the studied rocks include Cpx (except for HD), we have used a cpx-thermometer of Nimis and Taylor (2000) and a cpx-barometer of Ashchepkov (2001, 2002) to determinate P-T data of our rocks equilibrium. The temperatures for Harzburgite-Dunites were

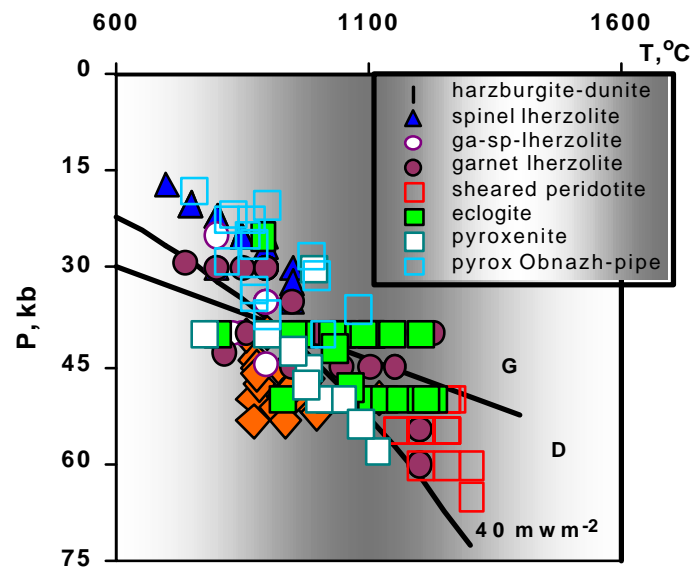

Figure 1: P-T conditions of equilibrium of mantle xenoliths from Yakutia and South Africa pipes. Pyroxenites from Obnazhennaya pipe xenoliths are shown as a separate group because it is the only nondiamondiferous pipe studied. 
calculated using a thermometer of O'Neil and Wood (1979), the pressures - using a barometer of Ryan (1996). The obtained P-T data are shown in Figure 1.

\section{GAS ÑHROMATOGRAPHY AND THERMODINAMIC CALCULATIONS}

The volatiles from the minerals of mantle xenoliths have been analyzed on a setup, assembled from three standard gas chromatographs LXM-80 and equipped with original device for thermic extraction of gases. This setup makes it possible to determine simultaneously all gases of interest $\left(\mathrm{CO}_{2}, \mathrm{H}_{2} \mathrm{O}, \mathrm{CH}_{4}\right.$, $\mathrm{H}_{2}, \mathrm{~N}_{2}, \mathrm{CO}, \mathrm{O}_{2}, \mathrm{C}_{2}-\mathrm{C}_{\mathrm{n}}$ ) from the same sample (Osorgin, 1990). The chromatographic data have been recalculated into the $\mathrm{PT}$ conditions of equilibrium of our rocks. The calculations have been made for $\mathrm{C}-\mathrm{O}-\mathrm{H}$ system in the presence of solid carbon using the $\mathrm{HCh}$ code (Y.V. Shvarov, MSU, Moscow). The code employs the minimization of Gibbs's free energy method. The calculations of fluid components were based on an assumption of a closed system, and therefore, a constant $\mathrm{H} /(\mathrm{O}+\mathrm{H})$ ratio for any reaction between the components of the system during temperature and pressure release after the rock transportation up to the surface and subsequent exhumation. Recalculations have been made for most minerals of the studied rocks, but mainly for $\mathrm{Ga}$ and $\mathrm{Ol}$, as those are the phases, which, structurally, have the highest chances to preserve the volatile phase in inclusions. Mean values of the main fluid characteristics are shown at the Table1.

\section{Table 1: The mean values of the main fluid parameters and redox characteristics of the mantle rocks}

\begin{tabular}{llllll} 
& $\mathrm{X}_{\mathrm{H} 2 \mathrm{O}}$ & $\mathrm{X}_{\mathrm{CO} 2}$ & $\mathrm{X}_{\mathrm{CH} 4}$ & $-\mathrm{lgfO}_{2}$ & $\mathrm{~h} /(\mathrm{h}+\mathrm{O})$ \\
\hline $\mathrm{HD}$ & 0.953 & 0.042 & 0.003 & 9.87 & 0.6501 \\
$\mathrm{GaL}$ & 0.924 & 0.063 & 0.008 & 9.90 & 0.6417 \\
$\mathrm{GaSpL}$ & 0.935 & 0.053 & 0.008 & 11.66 & 0.6435 \\
$\mathrm{SpL}$ & 0.915 & 0.068 & 0.012 & 12.95 & 0.6417 \\
$\mathrm{ShP}$ & 0.883 & 0.090 & 0.018 & 6.91 & 0.6307 \\
$\mathrm{Ecl}$ & 0.933 & 0.047 & 0.014 & 9.24 & 0.6526 \\
Pyx & 0.932 & 0.048 & 0.015 & 12.34 & 0.6521
\end{tabular}

\section{METHODS OF MATHEMATICAL STATISTICS}

We have attempted to distinguish different types of the mantle rocks on the basis of their redox characteristics and compositional peculiarities of the rock-forming minerals using methods of mathematical statistics.
The obtained samples of volatile components from mantle minerals and microprobe data have been classified with the help of a computer code, based on a special algorithm. The approximation of multidimensional distribution by the Rozenblat-Parzen method followed by the separation of zone of each mode as an independent cluster, is used as the basis for all factor, cluster, regressive and discriminant procedures. In this case, the metric of multiple space of the describing variables (i.e. their scale) transforms to minimize the entropy of approximated distribution (in the framework of linear transformations of coordinates which provide the value invariability for all hyper volumes). To choose the metric, the use of the entropic criterion eliminates the problem of correlation of scales for the values of various type (sizes, masses, frequencies, etc.), in fact making any table dimensionless. In this transformed space the factor axis are defined according to the method of main components and they are nonparametric. The formation of clusters is made step by step: first the zone of each mode of distribution is isolated as independent cluster, then the clusters, divided by shallow "saddles", unite (Ananiev, 1998). The values of the ratios of main oxides of the rock-forming minerals $\left(\mathrm{Fe}^{\prime}=\mathrm{FeO} /(\mathrm{FeO}+\mathrm{MgO}+\mathrm{MnO})\right.$,

$\mathrm{Cr}^{\prime}=\mathrm{Cr}_{2} \mathrm{O}_{3} /\left(\mathrm{Cr}_{2} \mathrm{O}_{3}+\mathrm{Al}_{2} \mathrm{O}_{3}+\mathrm{TiO}_{2}\right)$,

$\mathrm{Ca}=\mathrm{CaO} /(\mathrm{CaO}+\mathrm{MgO}+\mathrm{FeO})$,

$\mathrm{Na}=\mathrm{Na}_{2} \mathrm{O} /\left(\mathrm{Na}_{2} \mathrm{O}+\mathrm{K}_{2} \mathrm{O}+\mathrm{CaO}\right) \quad-$ for garnets and pyroxenes;

$\mathrm{Fe}^{\prime}=\mathrm{FeO} /(\mathrm{FeO}+\mathrm{MgO}+\mathrm{MnO})$,

$\mathrm{Cr}^{\prime}=\mathrm{Cr}_{2} \mathrm{O}_{3} /\left(\mathrm{Cr}_{2} \mathrm{O}_{3}+\mathrm{Al}_{2} \mathrm{O}_{3}+\mathrm{TiO}_{2}\right) \quad$ - for spinels; $\mathrm{Fe}^{\prime}=\mathrm{FeO} /(\mathrm{FeO}+\mathrm{MgO}+\mathrm{MnO})$,

$\mathrm{Ni}=\mathrm{NiO} /(\mathrm{NiO}+\mathrm{MgO}) \quad-$ for olivines $)$ and the fluid characteristics $\left(-\operatorname{lgfO}_{2}\right.$ and $\left.\mathrm{H} /(\mathrm{H}+\mathrm{O})\right)$ are used as the variables, separating the samples of harzburgite-dunite, garnet-, spinel-, garnet-spinel- and sheared lherzolites, eclogite and pyroxenite.

\section{RESULTS AND DISCUSSION}

As seen from Table 1, the studied rocks with similar $\mathrm{H} /(\mathrm{H}+\mathrm{O})$ ratios and insignificant variations of the mean values of the mole shares of the fluid main components, significantly differ in their $\operatorname{lgfO}_{2}$ and can be conditionally subdivided into three groups: SpLGaSpL-Pyx (-lg 12), HD-GaL-Ecl (-lg 9.5), ShP ($\lg 7$ ). Alternatively, according to the composition of garnet $\left(\mathrm{CaO}-\mathrm{Cr}_{2} \mathrm{O}_{3}\right)$, which is not a rock-forming mineral for $\mathrm{SpL}$ only, our samples can be subdivided as follows: $\mathrm{HD}$ ( $\mathrm{CaO} \sim 3$ wt.\%, $\mathrm{Cr}_{2} \mathrm{O}_{3} \sim 9$ wt.\%), GaLGaSpL-ShP (CaO 5.5 wt.\%, $\mathrm{Cr}_{2} \mathrm{O}_{3} \sim 6$ wt. \%), Ecl-Pyx (CaO 0.1-0.8 wt.\%, $\mathrm{Cr}_{2} \mathrm{O}_{3} \sim 5-8$ wt.\%). 


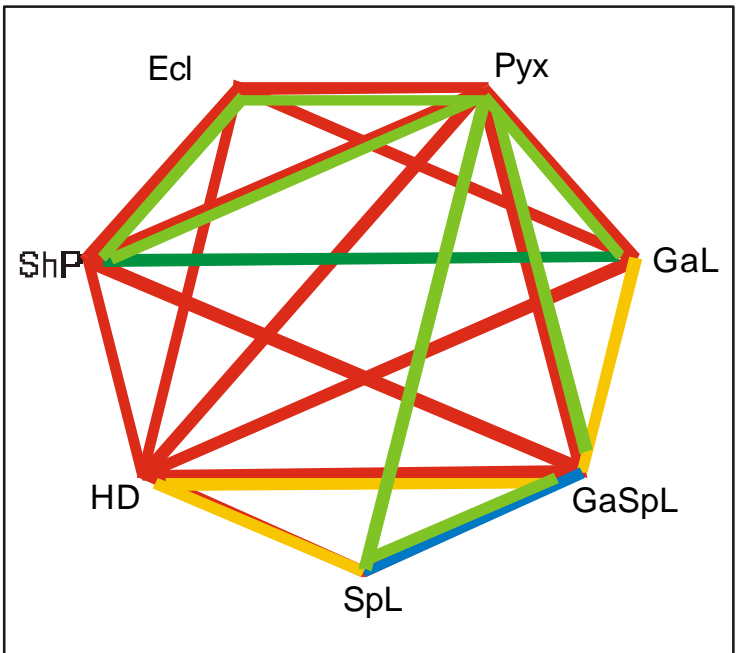

Figure 2: Scheme of comparison of mantle xenoliths of various genesis. The lines connecting the pairs of the mantle rocks are color-coded to show minerals, used to subdivide these rocks: red $-\mathrm{Ga}$, yellow $-\mathrm{Ol}$, blue $-\mathrm{Sp}$, green $-\mathrm{Cpx}$ (light) and Opx (dark).

Using the algorithm outlined above we have comp ared the studied samples. The comparison scheme is shown in Figure 2. First we compared and tried to divide the rocks conditionally classified as one and the same groups. Further the rocks similar in P-T data (Fig. 1) have been correlated.

$\mathrm{Ga}$ (as indicated above, is not present only in $\mathrm{SpL}$ ) and Cpx (is not present only in HD) are dominant minerals according to which the classification has been made. Ol (is not present in $\mathrm{Ecl}$ and Pyx), En and $\mathrm{Sp}$ were used only in a few cases. Figure 3 shows the results of the comparison. D1,2 for discrimination by Ga, Di or En (a, $\mathrm{c}, \mathrm{d}, \mathrm{f}, \mathrm{g}, \mathrm{h}, \mathrm{i}, \mathrm{j}, \mathrm{k})=\mathrm{a} 0+\mathrm{a} 1 \cdot \mathrm{Fe}^{\prime}+\mathrm{a} 2 \cdot \mathrm{Cr}^{\prime}+\mathrm{a} 3 \cdot \mathrm{Ca}^{\prime}+\mathrm{a} 4 \cdot$ $\mathrm{Na}^{\prime}+\mathrm{a} 5 \cdot(-\operatorname{lgfO} 2)+\mathrm{a} 6 \cdot(\mathrm{H} /(\mathrm{H}+\mathrm{O}))$, where $\mathrm{a} 0$ is the free term, a1, a2, a3, a4, a5, a6 are coefficients at $\mathrm{Fe}^{\prime}, \mathrm{Cr}^{\prime}$, $\mathrm{Ca}^{\prime}, \mathrm{Na}$ ', (-lgfO2), $\mathrm{H} /(\mathrm{H}+\mathrm{O})$, correspondingly; $\mathrm{D} 1,2$ for discrimination by $\mathrm{Ol}$ (e) $=\mathrm{a} 0+\mathrm{a} 1 \cdot \mathrm{Fe}+\mathrm{a} 2 \cdot \mathrm{Ni}^{\prime}+$ a3. $(-\operatorname{lgfO} 2)+\mathrm{a} 4 \cdot(\mathrm{H} /(\mathrm{H}+\mathrm{O}))$, where $\mathrm{a} 0$ is the free term, a1, a2, a3, a4 are the coefficients at Fe', Ni', (-lgfO2), $\mathrm{H} /(\mathrm{H}+\mathrm{O})$, correspondingly; $\mathrm{D} 1,2$ for discrimination by $\mathrm{Sp} \quad(\mathrm{b})=\mathrm{a} 0+\mathrm{a} 1 \cdot \mathrm{Fe}+\mathrm{a} 2 \cdot \mathrm{Cr}{ }^{\prime}+\mathrm{a} 3 \cdot(-\operatorname{lgfO} 2)+$ $\mathrm{a} 4 \cdot(\mathrm{H} /(\mathrm{H}+\mathrm{O}))$, where $\mathrm{a} 0$ is the free term, a1, a2, a3, a4 are the coefficients at $\mathrm{Fe}^{\prime}, \mathrm{Cr}^{\prime},(-\operatorname{lgfO} 2), \mathrm{H} /(\mathrm{H}+\mathrm{O})$, correspondingly.

Thus, using the bulk of the available data on the variations of chemical compositions of the rockforming minerals and oxygen fugacity of the rocks of various parageneses, we can reliably distinguish the sets of the mantle rocks, even when they are similar in P-T equilibrium conditions or in $\mathrm{fO}_{2}$. We interpret this as an indication of the fact that the upper mantle is heterogeneous, even within small areas. The variables for each paragenetic association are connected. This
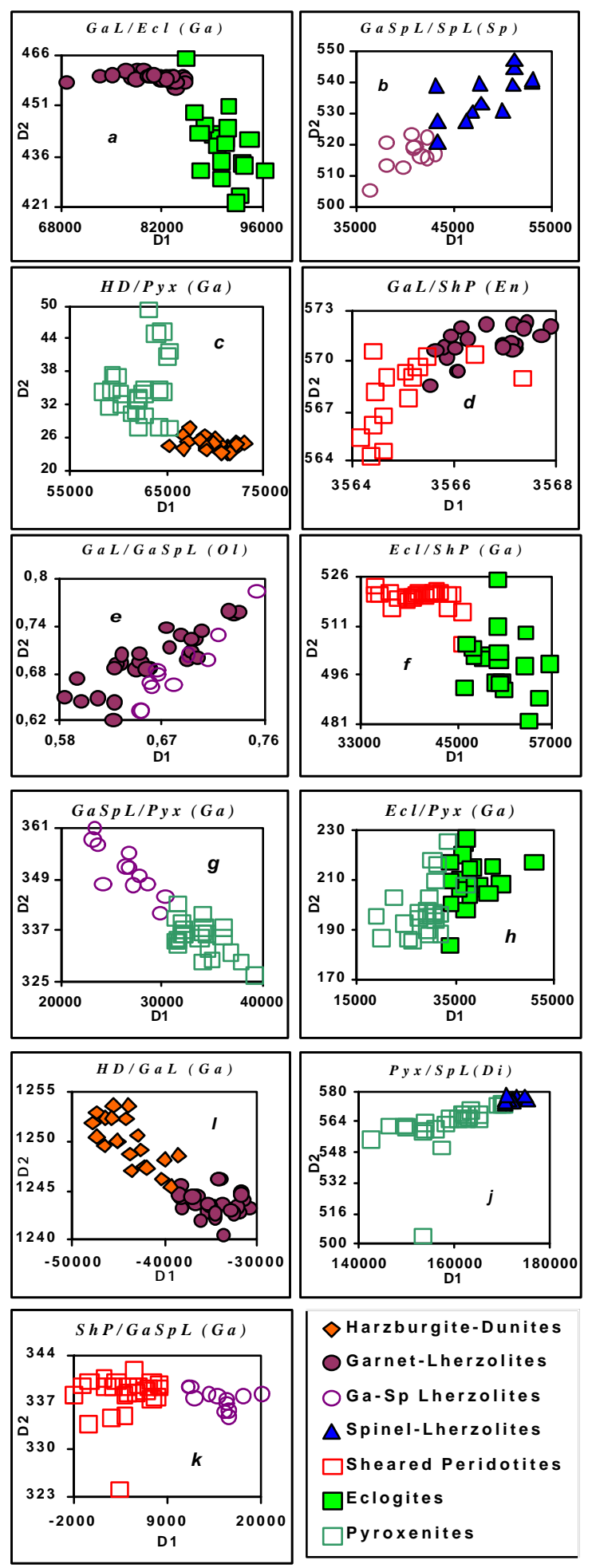

Figure 3: Optimized linear discriminative projections of the mantle rocks of different genesis.

connection makes it possible to separate these groups of rocks. The mathematical statistic methods prove useful in revealing this phenomenon. 


\section{ACKNOWLEDGMENTS}

The work was supported by the RFBR grants 00-0565418 and $01-05-65170$.

\section{REFERENCES}

Ananiev, V.A., Kuligin, S.S., Reimers, L.F., Khlestov, V.V., 1998. Paragenetic analysis of upper mantle minerals from the heavy mineral concentrates of kimberlites based on an original statistic method. Ext. Abs. $7^{\text {th }}$ Int. Kimb. Conf. Cape Town, South Africa, pp. 14-16.

Andersen, T., O'Reilly, S.Y., Griffin, W.L., 1984. The trapped fluid phase in upper mantle xenoliths from Victoria, Australia: implications for mantle metasomatism. Contrib. Mineral. Petrol. 88, 72-85.

Ashchepkov, I.V., 2001. Clinopyroxene Jd Barometer for Mantle Peridotites and Eclogites and Thermal Conditions of the Lithospheric Keels of Cratons and Their Surroundings. A Geo Odyssey. GSA Annual meeting. November 1-10, Boston. ID 11658.

Ashchepkov, I.V., 2002. An Empirical Clinopyroxene Thermobarometer for Mantle Rocks Based on the Jadeite-Diopside. Exchange Transactions of Russian Academy of Sciences. Earth Science section. 382, 78 -82 .

Daniels, L.R.M., Gurney, J.J., 1991. Oxygen fugacity constraints on the Southern African lithosphere. Contrib. Mineral. Petrol. 108, 154-161.

Jakobsson, S., Oskarsson, N., 1990. Experimental determination of fluid compositions in the system C$\mathrm{O}-\mathrm{H}$ at high $\mathrm{P}$ and $\mathrm{T}$ and low $\mathrm{fo}_{2}$. Geochimica et Cosmochimica Acta. 54(2), 355-362.

Kadik, A.A., 1999. The influence of redox state of the planetary substance on the formation of carbon saturated fluids in the upper mantle of the Earth. Institute of Geochemistry and Analytical Chemistry, RAS, Moscow, Vestnik OGGGGN RAN, 4(10) (in Russian).

Letnikov, F. A., 1999. Fluid facies of continental lithosphere and the problems of ore formation. Institute of Crust, SB RAS, Irkutsk, Vestnik OGGGGN RAN, 4(10) (in Russian).

Melton, C.E., Giardini, A.A., 1974. The composition and significance of gas released from natural diamonds from Africa and Brazil. Amer. Mineral. 59, 775-782.

Nimis, P., Taylor, W.R., 2000. Single clinopyroxene thermobarometry for garnet peridotites. Part I Calibration and testing of a Cr-in-Cpx barometer and an enstatite-in-Cpx thermometer. Contrib. Miner. and Petrol. 139 (5), 541-554.

O'Neil, H.S.C., Wood, B.J., 1979. An experimental study of $\mathrm{Fe}-\mathrm{Mg}$ partitioning between garnet and olivine and its calibration as a geothermometer. Contrib. Miner. and Petrol. 70, 59-70.

Osorgin, N.Yu.,1990. Chromatography of gases in minerals (methods, apparatus, metrology). IGG SO AN SSSR, Novosibirsk (in Russian).

Ryan, C.G., Griffin, W.L., Pearson, N.J., 1996. Garnet Geotherms: a technique for derivation of P-T data from Cr-pyrope garnets. Jour Geophys. Res. 101, 5611-5625.

Schrauder, M., Navon, O., 1994. Hydrous and carbonatitic mantle fluids in fibrous diamonds from Jwaneng, Botswana. Geochimica et Cosmochimica Acta. 58(2), 761-771.

Contact: LN Pokhilenko, IMP SB RAS, 3 Koptyuga ave., Novosibirsk, 630090, Russia, E-mail: lu@uiggm.nsc.ru 